\title{
Reading Dickens Romantically: “Night Walks”
}

\author{
Rukhsana Rahim Chowdhury \\ BRAC University, Dhaka, Bangladesh
}

\begin{abstract}
This paper will examine the essay, "Night Walks” (2000), to see how Charles Dickens (1812-1870), a social-realist writer of the Victorian era, has used elements adapted from the Romantics in order to draw attention to the pitiable social conditions of Victorian London. Dickens' the realist paradoxically reflected a readiness to think and feel “without immediate external excitement”. He expressed his alignment with Romanticism by way of a cultivation of feeling and empathizing. His genius was, as expressed by Bagehot, "essentially irregular and unsymmetrical” because he was "utterly deficient in the faculty of reasoning”. His daily, or rather nightly walks provided him with the inspiration to follow the Romantic tradition of writing on walks. The essay under consideration, "Night Walks", clearly supports the notion that Romanticism was fallaciously opposed to realism. The paper will examine the ways in which the theme, style, and structure of the essay evoke the preoccupation of a Romantic soul—for whom the walk becomes a space for "encounter and reflection"-and the Romantic mind which is empowered by "imaginative self definition or discovery".
\end{abstract}

Keywords: Romanticism, imagination, isolation, self-knowledge, human-mind

\section{Introduction}

"Some scholars see Romanticism as essentially continuous with the present”.

Lovejoy, The History of Ideas (1948)

Samuel Taylor Coleridge considers Romanticism as the beginning of a tradition of resistance to Enlightenment rationalism, Charles Baudelaire (2010) sees it, "situated neither in choice of subject nor exact truth, but in the way of feeling” and for Robert Hughes, Romanticism marks the inaugural moment of modernity. Although 20th century scholars have scoffed at what they call "emotionalism" that this emotionalism was sometimes exaggerated should not obscure the fact that it also contained much that was genuine and inspiring. So much so that although scientific advances and global social changes in the 19th century had a profound effect on literature, creating a sense of loss and despair, the Victorian era continued promoting the Romantic ideals of love and affinity with nature. It was a time when, it will be pertinent to recall, England was veering away from rationalism and showing a renewed interest in religious mysticism, idealism and Romanticism. These were the cultural trends and influences which inspired Victorian writers like Lewis Carroll to use a mixture of logic, realism, fantasy, and absurdity in his book Alice's Adventures in Wonderland and Matthew Arnold to sometimes reflect quite a meditative, elegiac tone in his poetry. Tennyson with his Lady of Shalott and poems dealing with the Arthurian legend was also clearly influenced by the ideals of Romanticism.

Rukhsana Rahim Chowdhury, senior lecturer, Department of English and Humanities, BRAC University. 


\section{Romanticism Fallaciously Opposed to Realism}

Charles Dickens (1812-1870), a social-realist writer, was greatly influenced by the Romantics. He grew up under the influence of the Romantic Movement's fascination with feeling, emotion, imagination, and states of marginal consciousness. Dickens, the realist, who paradoxically, reflected a readiness to think and feel "without immediate external excitement” expressed his alignment with Romanticism by way of a cultivation of feeling and empathizing. His genius was, as expressed by Bagehot, "essentially irregular and unsymmetrical” because he was "utterly deficient in the faculty of reasoning". His writings and especially the essay under consideration, "Night Walks”, clearly support the notion that Romanticism was fallaciously opposed to realism. Historian Jaques Barzun declared that “ ...the Romantic realist does not blink his weakness, but exerts his power” (Jacques, 1755, p. 77). For Dickens, this power which was a vehicle for social change was exerted through an involvement in the life of the common people, bringing him into "sympathetic relations with people" (Dickens, 2000, p. 147).

He transformed this empathy for the sufferings of others into a medium for social reform, as is evident in this essay. "Night Walks" was originally published in the weekly journal, All Year Round in 1859. Later it appeared as chapter 13 of The Uncommercial Traveller in 1861. He wrote this essay at a time when he suffered from insomnia and decided that the best way to cope with the problem was to leave his bed and walk the streets of London and return at last in the early hours of dawn to a restfully peaceful sleep. This paper will examine the essay, "Night Walks" to see how Dickens has used the concept of imagination that he adapted from the Romantics to highlight the pitiable social conditions of Victorian London.

The English Romantic poets were clearly inspired by their long walks: Wordsworth and Coleridge in the idyllic Lake District of England and Shelley in Italy. Dickens here was clearly inspired by the Romantic tradition of peripatetic writings. Walking which is usually a physically and spiritually uplifting experience, translated into an obsession for Dickens. His walks resulted in a lament of the sickening condition of London. He describes the back alleys of this Victorian city as "the filthiest, the strangest, and the most extraordinary of the many localities that are hidden in London” (Dickens, 1994, chapter 50). But this obsessive interest in the lives of the homeless poor of London resulted in a social criticism having far reaching effects on the lives of people globally. His descriptions of the mistreatment of children helped initiate child labor reform culminating in the Great Reform Act of 1832.

The essay, "Night Walks” has almost a surreal feel to it. It reads like an exercise in meditation. Elements like imagination, emotion, nature, and Gothicism are clearly evident here. The very idea and style of the essay is evocative of Rousseau's "Reveries of a Solitary Walker" written between 1776 and 1778 where the French philosopher described sights he encountered on his walks around Paris and recorded his introspective interaction of the mind and the world around him. According to Clark (1996):

It may be compared to that minor genre of Romantic writing that dramatizes the meditations of a walk, such as Hazlitt’s “On Going a Journey”, various essays by De Quincey or Leigh Hunt’s “Walking Home by Night”. The walk in the poetry of Wordsworth and Coleridge ... engages the writer in the dramatization of a dialectical interaction between mind and world. It is a space of encounter and reflection; it enacts a drama of consciousness [...gained through....] topics suggested by the walk in progress and empowerment of the mind in imaginative self definition or discovery. (p. 35)

Dickens's personal life was full of trials and tribulations. Private misery left indelible marks on his work. His mother's insistence that he continued working at the shoe blacking factory, even after his father's released from the debtor's prison, scarred him emotionally for the rest of his life: 
No words can express the secret agony of my soul as I ... felt my early hopes of growing up to be a learned and distinguished man crushed in my breast. The deep remembrance ... of the misery it was to my young heart to believe that, day by day, what I had learned and thought, and delighted in, and raised my fancy and emulation up by, was passing away from me ... cannot be written. (Forster, 2008, p. 53)

In flight from physical problems like insomnia and internal troubles like being haunted by the past, the narrator-walker starts out "under a compulsion to walk and walk and walk in the darkness and pattering rain" and by doing so, successfully captures the romance and ecstasy of misery, isolation and wretchedness that he encounters on the streets of London. His use of personification and imagery dramatizes the inner and the outer forms of the human universe. Personification is used when the very city of London seems to share the walker's anguish and experiences the same fits and starts of a restless sleeper in "the way in which it tumbles and tosses before it can get to sleep" (Dickens, 2000, p. 122). The hour itself, that of night, is highly Romantic, coupled with the "wild moon" and the clouds. The moon in the Romantic tradition is identified with imagination, and the night is associated with silence and solitude and therefore provides an ability to meditate and communicate easily with nature. For expressing this highly Romantic theme, Dickens, the ultimate artist employs the tool of a simple, plain and emphatic language which for Wordsworth is "a more permanent and a far more philosophical language” (Wordsworth, 1991, p. 245). The essay has quite a few Wordsworthian echoes. The lines, " ...the buildings on the banks were muffled in black shrouds ... the very shadow of the immensity of London seemed to lie oppressively upon the river" (Dickens, 2000, p. 124) are like mirror-images of Wordsworth's, "Dear God! The very houses seem asleep;/And all that mighty heart is lying still!” (Wordsworth, 1807, p. 82).

\section{Dreams and Literary Creations}

Dickens had a magnificent technique of externalizing inner mental conflicts. He did not talk about the mental processes of his characters but showed their troubled lives reflected in the surroundings and social conditions. The oppressive shadows, silence, and the dimness of light gave a whole new dimension to every encounter that the troubled walker, the "houseless mind" or "houselessness" had. The familiar daily sights took on a wholly different form of visibility. The people and the places took on a fascinatingly remote and eerie air, denoting his own uneasy feeling of vagueness and isolation. The author's state of self knowledge was subject to the influence of strong emotions. It gave him matter for reflection to walk past "that wicked little Debtor's Door" at Newgate and be reminded of the prisoners, "many quite innocent" (Dickens, 2000, p. 125). Like a true Romantic, the walker feels like "lamenting the good old times and bemoaning the present evil period" (Dickens, 2000, p. 125) experiencing a kind of night fancy as he approached Bethlehem, an asylum for the insane. The physical reality of the asylum and its inmates evoked a much deeper metaphysical reality. Dickens grew up under the influence of the Romantic Movement's fascination with states of marginal consciousness and the Victorian dream books and magazines carried works on spiritual accounts of revelatory dreams. His personal collection comprised of more than 30 books on topics ranging from physiological psychology to miscellanies on the spirit world covering ghosts, apparitions, omens, dreams, daemons and "Other Magical Practices" as written on the cover of an 18th century book. All the Romantic writers considered that there was a strong link between dreams and the processes of literary creation. Byron produced what might be called the Romantic Manifesto on dreams by ruling that the three cardinal Romantic doctrines on dreams are that they are a revelation of reality, they can form and influence waking life, and the dream process is a parallel and model of the process of poetic creation (Lewes, 1865, p. 70). 
An important dream postulated by Aristotle held special significance for the Romantics and especially Coleridge and Keats: "Nor is every presentation which occurs in sleep necessarily a dream. For in the first place, some person when asleep, actually perceive sounds, light etc., for there have been cases in which persons while asleep but with eyes partially open, saw faintly in their sleep the light of a lamp, and afterward on being awakened, straight away recognized it as the actual light of a real lamp ... but none of these occurrences should be called a dream”. Coleridge referred to these as reveries. Dickens' novel The Mystery of Edwin Drood focuses on the opium induced reverie of the central character. Dreams as sources and techniques and especially the Aristotelian Dream Theory were important to the Romantics, and they valued and used their own dreams (Lewes, 1865, p. 69). Charles Dickens is also known to have used his own dreams as "aesthetic experiences of intrinsic value" for his creative fiction.

Coleridge's fascination with the creative sources of the imagination, and Wordsworth's preoccupation with recollection of childhood memories show a remarkable influence on Charles Dickens. Approaching Bethlehem, the walker is struck by the realization that we are "troubled by our own sleeping inconsistencies" just as the insane are by their "waking delusions". Thereby, indicating his shocking idea that the perils of industrialization and pressures of living in a modern society have thrown the sane and the insane together, at least at some paranormal level. He thinks that the state of the insane is not particularly different from the state of the sleeping sane. "Are not the sane and the insane equal at night as the sane lie a dreaming?" This question beautifully internalizes the external. Dickens recalls problems of sane Londoners and implies that they too are driven by their demons just like these inmates, some of whom in ironic contrast to their situation regard themselves as kings and queens in their waking hours. In quite a Romantic manner, Dickens had entertained royalty in his dream in his childhood years. This dream contrasted sharply with his poverty stricken reality. He had in fact, used his imagination to suspend reason. Imagination can effectively control perception making the mind work in which Freud would call a primary process that dominates dreams and allows one to attain an ideal. According to Higbie (1998):

The versions of the ideal that Dickens imagines seem to be versions of a return to a paradise childhood world in which his parents had not failed him, and to a pre-Oedipal infantile union with a mother whom he could still see as loving and totally wish fulfilling. (p. 60)

George Henry Lewes in "Dickens in Relation to Criticism", arguing about the mental processes that feed the hallucinations of the insane and their belief in the reality of their visions, said that for Dickens "revived images have the vividness of sensations; ...created images have the coercive force of realities, excluding all control, all contradiction" (Lewes, 1865, p. 145). Lewes finds the glorious energy of imagination, a force "so definite" that even while knowing that the image created by imagination is false, "we could not help for a moment, being affected by his hallucination". He also said, "Dickens sees and feels but the logic of feeling seems the only logic he can manage” (Lewes, 1865, p. 151).

\section{Drawing Inspirations From Romantic Tradition}

Romantic poets such as Blake and Wordsworth celebrated the innocent world of children. The theme is borrowed by Dickens in his writing where the figure of the exploited and orphaned child is pivotal. His own childhood sufferings and a profound sense of loneliness made him acutely aware of the Romantic notion of childhood and cultivated an empathetic feeling for what he described as the "ragged, homeless, urchin". Most of 
these child labourers were orphans or abandoned children and therefore exposed to exploitation, physical injury, emotional trauma and even death. This depiction may be traced back to the experience of a twelve-year-old Charles forcibly sent to work at Warren's Blacking due to his father's imprisonment for debt and is reminiscent of Blake who was also a harsh critic of child labour. Dickens' portrait of these child labourers echoes Blake's depiction of the young chimney sweeps in 18th century England. It was this criticism of society which produced reforms in child labour laws towards the end of the 19th century.

The night walker saw children sharing sleeping space under the vegetable wagons with the sharp dogs in the Covent Garden market. These were children who after spending a day fighting for offal, diving for anything they can steal, hiding from the constables, running around in bare feet in the cold rain finally finding a resting place in the vegetable baskets. He compared the growth of corruption in these uncared for and ever-hunted "savages" with the growth of corruption in civilized society. These children reminded Dickens of Rousseau's "savages" as industrialization and the ills of modern society had compelled these innocents to be driven primarily by their immediate needs like food, sleep, fear of hunger, pain, and self preservation. This portrayal of children by Dickens reinforces Rousseau's concept of children existing in-according to Newsom in his essay, "Fictions of Childhood"- an original, natural, even prelapsarian state and thus deserving society's care and attention so that their innocence can be preserved. The reader also notes that despite the harshness of their situation, the world of these children is filled with innocence and naivety, as these "savages" seem ignorant of their rights and position in society.

As the walk progresses towards yet another prison, the tone darkens, and his anxiety, awareness and the emotions which he found complex and indefinable or vague, found expression in a reworking of the Gothic element which is apparent in the very Coleridgean description of the "Dry Rot in Men". We are reminded of the nightmarish experience of the ancient mariner who had committed a sin against humanity and was subsequently punished to a life-in-death experience. Just as the dreadful figure of Death makes each sailor cast one accusing condemning look at the mariner before dropping lifelessly, one by one at his feet, the walker too noticed how the dry rot in men consumes them hollow for indulging in corruption and committing unpardonable acts of cruelty.

For Coleridge, reverie meant a waking dream in which the mind though remaining aware relaxed its monitoring and allowed the imagination to roam freely in a process of association. Dickens exhibits a vivid display of just such Romantic imagination when he associates stories with people he notices at this late hour: the criminal's shadow in the doorway, the toll-keeper at the bridge, the dead body of a murdered man, the pudding eater's mother evoking memories of his own mother. The red-faced pudding eater in the coffee house at Covent Garden Market mentioned that his mother "was a red-faced woman that liked drink, and I looked at her hard when she laid in her coffin, and I took the complexion” (Dickens, 2000, p. 129). This grotesquely gothic association completely puts off the night walker for whom "the pudding seemed an unwholesome pudding after that, and I put myself in its way no more” (Dickens, 2000, p. 129).

\section{Conclusion}

The essay again takes on a very realistic and prosaic tone towards the end, when night fades away and the first rays of the sun hit London city and the author comments that daylight hides the vice and misfortune that night reveals. But even while doing so, it also follows the traditional structure of writings on walks by the Romantics, where the end brings some sort of a resolution. For Dickens' walker, it brings daylight and the much coveted sleep: “the day came and I was tired and could sleep” (Dickens, 2000, p. 130). 
The theme, style, and structure of the essay evoke the preoccupation of a Romantic soul-for whom the walk becomes a space for "encounter and reflection"-and the Romantic mind which is empowered by "imaginative self definition or discovery". As Oates (1999) said, "This haunting essay seems to hint at more than its words reveal. No one has captured the romance of desolation, the ecstasy of near-madness, more forcibly than Dickens” (p. 1).

\section{References}

Clark, T. (1996). Dickens through Blanchot: The nightmare fascination of a world without interiority. In J. Schad (Ed.), Dickens refigured: Bodies, desires and other histories (p. 35). Manchester: Manchester University Press.

Baudelaire, C. (2010). Baudelaire's speech at the "Salon des curiosités Estethiques". Retrieved from http://fr.wikisource.org/wiki/Salon_de_1846_\%28Curiosit\%C3\%A9s_esth\%C3\%A9tiques\%29\#II._.E2.80.94_Qu.E2.80.99e st-ce_que_le_romantisme.3F

Darrin, M. M. (1998). The counter-enlightenment and the low-life of literature in pre revolutionary France. Past and Present, 159(77-112), 79.

Dickens, C. (2000). Night walks. The uncommercial traveller (pp. 122-130). Retrieved from www2.hn.psu.edu/faculty/jmanis/dickens/travel.pdf

Dickens, C. (1994). Oliver twist. London: Penguin Books.

Forster, J. (1927). Life of Charles Dickens. London \& Toronto: J. M. Dent \& Sons.

Hayter, A. (1968). Opium and the Romantic imagination. Berkeley and Los Angeles, California: University of California Press.

Higbie, R. (1998). Dickens and imagination. Gainesville: University Press of Florida.

Lewes, G. H. (1865). Dickens in relation to criticism. Fortnightly Review (pp. 69-70, 145-151). London: Chapman and Hall. Retrieved from http://catalog.hathitrust.org/api/volumes/oclc/1781612.html

Simon, L., \& Hughes, R. (2004). Book world—Reviews—The sleep of reason—Goya. The World \& I, 19(2), 210.

Lovejoy, A. O. (1948). On the discrimination of Romanticisms. The History of ideas (pp. 545-549). Retrieved from http://www.jstor.org/stable/2909304

Newsom, R. (2001). Fictions of childhood. The Cambridge companion to Charles Dickens (p. 92). Retrieved from http://dx.doi.org/10.1017/CCOL0521660165.008

Oates, J. C. (1999). To invigorate literary mind, start moving literary feet. The New York Times, p. 1.

Rousseau, J. J. (1755). Discourse on the origin of inequality. London: R. and J. Dodsley.

Berlin, I., \& Hardy, H. (2000). Three critics of the enlightenment: Vico, Hamann, Herder. Princeton, N.J.: Princeton University Press.

Bagehot, W. (1858). The national review. New York: National Review.

Wordsworth, W., \& Coleridge, S. T. (1991). The lyrical ballads (2nd ed.). R. L. Brett, \& A. R. Jones, (Eds.). London: Routledge.

Wordsworth, W. (1998). Composed upon Westminster bridge. In S. Logan (Ed.), Selected poems (p. 82). London: Everyman. 